\title{
PENAMBAHAN LARUTAN BAWANG MERAH (Allium cepa L.) DAN AIR KELAPA (Cocos nucifera L.) SEBAGAI FITOHORMON ALAMI PADA PERTUMBUHAN TANAMAN TEBU (Sacchanum officinarum L.) SEBAGAI SUMBER BELAJAR BIOLOGI
}

\author{
Dewi Kurniawati ${ }^{1}$ \\ HRA. Mulyani ${ }^{2}$ \\ Rasuane Noor $^{3}$ \\ 1, 2,3, Pendidikan Biologi Universitas Muhammadiyah Metro \\ E-mail: 1 dewikurniawati889@gmail.com 르ra.mulyani@gmail.com ${ }^{3}$ rasuanenoor@gmal.com
}

\begin{abstract}
This study aims to 1) to see the effect of natural phytohormones in onions and coconut water on the growth of sugarcane, 2) To see the effect of giving natural phytohormones to sugarcane plants which produce the best growth, 3) To see the results of research on the growth of sugarcane can be used biology learning resources. This type of research is an experimental study using a completely randomized design (CRD). This study consisted of 4 treatments, namely, the first treatment was giving sand and red soil, the second treatment was giving manure and $15 \%$ concentration of onion solution phytohormones, the third treatment was giving manure and phytohormones with $25 \%$ concentration of coconut water solution, the fourth treatment was Pembrian. Manure and phytohormone combined with $15 \%$ concentration of onion solution + phytohormone with $25 \%$ concentration of coconut water solution. The parameters observed in this study were height in units (cm), number of leaves (counting manually), stem diameter in units $(\mathrm{cm})$. To determine the effect of phytohormone solutions on shallots and coconut water, data analysis was carried out using the one-way ANOVA test. and further tests to find out the most optimum treatment for the growth of sugarcane using the BNJ test. Based on the research, there was a significant effect of giving natural phytohormones on the growth of sugarcane, with the best treatment, namely the third treatment of giving manure and phytohormones of coconut water solution. The results of this research can be used as a source of learning biology in the form of videos with material on the growth and development of class XII.
\end{abstract}

Kata kunci: larutan bawang merah (allium cepa L), air kelapa (cocos nucifera L), fitohormon, tanaman tebu.

\section{PENDAHULUAN}

Produksi tanaman tebu

(Saccharum officinarum L.). di Indonesia cenderung mengalami peningkatan setiap tahunnya. Hal ini dikarenakan tanaman tebu sebagai salah satu komoditas yang dapat memberikan kontribusi terhadap peningkatan dan kesejahteraan masyarakat terutama bagi petani tebu dan para pelaku usaha. Tanaman tebu (Saccharum officinarum L.) adalah salah satu tanaman yang sangat dibutuhkan oleh masyarakat Indonesia karena nilai ekonomisnya tinggi dan harga jualnya relatif mahal. Tebu (Saccharum officinarum L.) merupakan salah satu jenis tanaman yang hanya dapat ditanam di daerah yang memiliki iklim tropis. Di Indonesia, perkebunan tebu menempati luas area \pm 321 ribu hektar yang $64,74 \%$ diantaranya terdapat di Pulau Jawa (Misran, 2005).

Produksi gula belum dapat memenuhi kebutuhan konsumsi dalam negeri sehingga masih diperlukan impor gula. Berbagai upaya telah dilakukan untuk menutupi kekurangan produksi gula ini antara lain memperluas areal 
tanaman tebu baik yang diusahakan oleh pabrik gula maupun petani (areal tebu rakyat), meningkatkan produktivitas tanaman tebu melalui program intensifikasi (Nur \& Ernawati, 2017).

Dengan cara melakukan Intensifikasi pertanian yang sangat penting untuk meningkatkan hasil pertanian dengan cara mengoptimalkan lahan pertanian yang sedikit dan menghasilkan produksi yang besar. Cara intensifikasi yang baik dengan cara pengolahan tanah yang baik, pemilihan bibit unggul, irigasi yang teratur (pengairan), pemupukan dan meningkatkan produksi dengan salah satunya meningkatkan fitohormon.

Fitohormon merupakan senyawa yang dalam jumlah sedikit tetapi dapat berpengaruuh besar terhadap pertumbuhan dan produksi tanaman. Fitohormon pendorong terdiri dari IAA (auksin), Gibberelin, Zeatin (sitokinin), sedangkan fitohormon penghambat terdiri dari ABA (Abscisic Acid L.), etilen dan senyawa fenolit. Fitohormon ini mampu diproduksi oleh mikroorganisme tertentu dan juga dapat dihasilkan oleh tanaman yang dapat mempengaruhi proses fisiologis tumbuhan (Agustian dkk, 2010).

Penanaman menggunakan fitohormon alami yaitu bawang merah (Allium cepa L.) pada fitohormon ini akan menimbulkan pertumbuhan dan perkembangan tumbuhan. Bawang merah dapat digunakan sebagai alternatif pengganti fitohormon alami selain itu kandungan hormon pada bawang merah adalah auksin dan giberelin yang meningkatkan pertumbuhan benih. Auksin sangat berpengaruh terhadap perpanjangan akar, sedangkan giberelin akan merangsang pertumbuhan daun dan batang (Ngatimin, dkk 2019).

Pada fitohormon alami air kelapa (Cocos nucifera L.) dalam bidang pertanian air kelapa dapat digunakan sebagai bahan untuk membantu proses pertumbuhan tanaman air kelapa sebagai zat pengatur tumbuh dalam perbanyakan tanaman secara vegetatif. Adapun yang terkandung pada air kelapa yaitu auksin mencapai $60 \%$ dan sitokinin mencapai 20\% ( Khair dkk, 2013).

Berdasarkan sumber belajar proses pembelajaran yang diperoleh yaitu pertumbuhan dan perkembangan yang berupa video yang sangat membantu untuk mecapai efektifitas pembelajaran khususnya pada mata pembelajaran yang mayoritas praktek. Media video yang dapat mentransfer pengetahuan dan dapat digunakan sebagai bagian dari proses belajar, berdasarkan latar belakang diatas, maka dapat dirumuskan judul Pengaruh Larutan Bawang Merah (Allium Cepa L.) dan Air Kelapa (Cocos nucifera L.) sebagai Fitohormon Alami pada Pertumbuhan Tanaman Tebu (Sacchanum officinarum L.)sebagai Sumber Belajar Biologi.

\section{METODE}

Penelitian ini menggunakan metode eksperimen dengan Rancangan Acak Lengkap (RAL) dengan variabel bebas penambahan larutan fitohormon bawang merah dan air kelapa, sedangkan variabel terikat yaitu pertumbuhan tanaman tebu yang meliputi tinggi, jumlah daun dan diameter batang tanaman. Penelitian ini terdiri dari 4 perlakuan dan 6 ulangan. Dalam penelitian ini yang merupakan populasi adalah bibit tanaman tebu yang telah 
dipilih dan penanamn dilakukan dengan memotong batang tebu dengan panjang $15 \mathrm{~cm}$.

Menyiapkan 24 batang tebu yang sudah dipotong sesuai ukuran, selanjutnya menyiapkan tanah pasir dan tanah merah serta pupuk kandang. Menyiapkan media tanam perlakuan antara lain adalah 6 polybag berisi tanah pasir dan tanah merah, 6 polybag tanah pasir dan tanah merah yang sudah dicampurkan dengan pupuk kandang yang akan diberi perlakuan larutan bawang merah, 6 polybag tanah pasir dan tanah merah yang sudah dicampurkan dengan pupuk kandang yang akan diberi perlakuan larutan air kelapa, 6 polybag tanah pasir dan tanah merah yang sudah dicampurkan dengan pupuk kandang yang akan diberi perlakuan larutan kombinasi bawang merah dan air kelapa.

Data hasil penelitian dianalisis menggunakan uji ANAVA satu arah dengan uji syarat yaitu uji normalitas (,Liliefors), uji homogenitas (Barlett), uji hipotesis, dan uji BNJ (Beda Nyata Jujur). Hasil penelitian analisis menggunakan uji Normalitas didapat $\mathrm{L}_{0}<\mathrm{L}_{\mathrm{daf}}$, hasil uji menggunakan uji homogenitas didapat $\mathrm{X} 2_{\text {hitung }}<\mathrm{X} 2$ daftar, uji hipotesis didapat $\mathrm{F}_{\text {hitung }}>\mathrm{F}_{\text {daftar }}$ dan uji lanjut $\mathrm{BNJ}$ menunjukan bahwa perlakuan P3 pemberian pupuk kandang dan pemberian fitohormon air kelapa memiliki perlakuan terbaik.

\section{HASIL}

Tabel 1. Tabel Pertumbuhan Tinggi Tanaman Tebu Minggu Ke 1 Sampai Ke 8 Dengan Satuan (cm)

\begin{tabular}{ccrrrrrrr}
\hline Perlakuan & $\mathbf{1}$ & $\mathbf{2}$ & $\mathbf{3}$ & $\mathbf{4}$ & $\mathbf{5}$ & $\mathbf{6}$ & $\mathbf{7}$ & $\mathbf{8}$ \\
\hline P1 & 9,1 & 16,3 & 32,3 & 55,1 & 79 & 100,2 & 114,3 & 132 \\
P2 & - & 7,5 & 20,1 & 31,8 & 70,3 & 107,3 & 131,8 & 151,1 \\
P3 & 12,3 & 22 & 41,6 & 63 & 109,5 & 139,3 & 169,3 & 187,8 \\
P4 & 2,3 & 11,3 & 28,1 & 40,3 & 109,6 & 114,6 & 134,8 & 153 \\
\hline
\end{tabular}

Keterangan:

P1= Perlakuan 1 dengan menggunakan tanah merah dan tanah pasir yang dilakukan para petani tebu.

P2= Perlakuan 2 pemberian pupuk kandang dan pemberian fitohormon bawang merah sebanyak $15 \%$ setiap satu minggu sekali dengan 6 kali ulangan.

P3= Perlakuan 3 pemberian pupuk kandang dan pemberian fitohormon air kelapa sebanyak $25 \%$ setiap satu minggu sekali dengan 6 kali ulangan.

P4= Perlakuan 4 pemberian pupuk kandang dan pemberian campuran fitohormon bawang merah dan air kelapa sebanyak $40 \%$ setiap satu minggu sekali dengan 6 kali ulangan.

Tabel 2. Tabel Jumlah Daun Tanaman Tebu minggu ke 1 sampai minggu ke 8

\begin{tabular}{ccccccccc}
\hline Perlakuan & $\mathbf{1}$ & $\mathbf{2}$ & $\mathbf{3}$ & $\mathbf{4}$ & $\mathbf{5}$ & $\mathbf{6}$ & $\mathbf{7}$ & $\mathbf{8}$ \\
\hline P1 & 2 & 4 & 5 & 7 & 8 & 6 & 9 & 10 \\
P2 & - & 1 & 3 & 7 & 8 & 10 & 12 & 11 \\
P3 & 3 & 5 & 7 & 10 & 11 & 11 & 13 & 14 \\
P4 & 1 & 3 & 5 & 6 & 9 & 11 & 12 & 13 \\
\hline
\end{tabular}

Keterangan:

P1= Perlakuan 1 dengan menggunakan tanah merah dan tanah pasir yang dilakukan para petani tebu.

P2= Perlakuan 2 pemberian pupuk kandang dan pemberian fitohormon bawang merah sebanyak $15 \%$ setiap satu minggu sekali dengan 6 kali ulangan.

P3= Perlakuan 3 pemberian pupuk kandang dan pemberian fitohormon air kelapa sebanyak $25 \%$ setiap satu minggu sekali dengan 6 kali ulangan. 
P4= Perlakuan 4 pemberian pupuk kandang dan pemberian campuran fitohormon bawang merah dan air kelapa sebanyak $40 \%$ setiap satu minggu sekali dengan 6 kali ulangan.

Tabel 3. Diameter Batang Tanaman Tebu Minggu Ke 1 Sampai Minggu Ke 8 Dengan Satuan $(\mathrm{cm})$

\begin{tabular}{ccccccccc}
\hline Perlakuan & $\mathbf{1}$ & $\mathbf{2}$ & $\mathbf{3}$ & $\mathbf{4}$ & $\mathbf{5}$ & $\mathbf{6}$ & $\mathbf{7}$ & $\mathbf{8}$ \\
\hline $\mathbf{P 1}$ & 1,6 & 1,8 & 2 & 2,6 & 2,8 & 3,3 & 3,8 & 4,5 \\
$\mathbf{P 2}$ & - & 1,5 & 1,9 & 2,4 & 2,9 & 3,7 & 4,9 & 5,7 \\
$\mathbf{P 3}$ & 1,7 & 2,7 & 3,4 & 4,2 & 5 & 4 & 6,2 & 7 \\
$\mathbf{P 4}$ & - & 1,4 & 1,9 & 2,1 & 3,2 & 3,7 & 4,4 & 5,1 \\
\hline
\end{tabular}

Keterangan:

$\mathrm{P} 1=$ Perlakuan 1 dengan menggunakan tanah merah dan tanah pasir yang dilakukan para petani tebu.

$\mathrm{P} 2=$ Perlakuan 2 pemberian pupuk kandang dan pemberian fitohormon bawang merah sebanyak $15 \%$ setiap satu minggu sekali dengan 6 kali ulangan.

P3= Perlakuan 3 pemberian pupuk kandang dan pemberian fitohormon air kelapa sebanyak $25 \%$ setiap satu minggu sekali dengan 6 kali ulangan.

$\mathrm{P} 4=$ Perlakuan 4 pemberian pupuk kandang dan pemberian campuran fitohormon bawang merah dan air kelapa sebanyak $40 \%$ setiap satu minggu sekali dengan 6 kali ulangan.

\section{PEMBAHASAN}

\section{Pertumbuhan Tinggi Tanaman}

Tebu (Saccharum officinarum L.)

Pertumbuhan dan perkembangan suatu tanaman tidak terlepas dari kebutuhan akan unsur hara. Unsur hara yang berperan dalam proses pertumbuhan tanaman tebu, dalam penelitian ini adalah unsur hara nitrogen. Unsur hara nitrogen berperan dalam proses pembentukkan protoplasma sel, terutama pada pembentukkan akar, batang dan jumlah daun tanaman. Kebutuhan tanaman tebu akan hara nitrogen telah dipenuhi dari media tanam yang diberikan, yaitu tanah pupuk kandang kotoran kambing yang kaya akan nitrogen. Salah satu usaha meningkatkan produksi dengan memperbaiki kesuburan tanah melalui pemupukan baik menggunakan pupuk organik maupun pupuk anorganik. penggunaan pupuk kandang dalam penelitian merupakan salah satu cara untuk mengatasi kesuburan tanah (Safitri dkk, 2017)

Pertumbuhan tinggi tanaman tebu yang dihasilkan dalam penelitian ini juga dibantu dari fitohormon alami yang diberikan pada tanaman tebu. Fitohormon merupakan senyawa organik bukan nutrisi yang dapat meningkatkan pertumbuhan dan perkembangan suatu tumbuhan (Muswita, 2011). Fitohormon juga sebagai zat-zat yang dapat merangsang pertumbuhan dan mengatur proses fisiologi tanaman (Sukmadi dan Bambang, 2012). Jenis-jenis fitohormon antara lain adalah hormone auksin, sitokinin, etilen, gibrelin, brasinusteroit, dan asam absisat.

Berdasarkan data hasil uji statistika tentang tinggi tanaman tebu dapat diketahui bahwa semua perlakuan berdistribusi normal $\mathrm{Lo}<\mathrm{L}_{\text {daf }} 0,364$ berarti terima $\mathrm{h}_{0}$ maka dapat disimpulkan bahwa sampel berasal dari populasi berdistribusi normal. Data yang berdistribusi normal maka akan dilanjutkan ke uji homogenitas, setelah melakukan uji homogenitas dapat diperoleh bahwa diperoleh $x^{2} \quad 1,61<x^{2}{ }_{(1-0,01(4-1)} 11,34$ dari tabel chi kuadrat yang berarti Ho diterima sehingga dapat disimpulkan bahwa sampel bervariasi homogen, dikarenakan data homomegen maka dialanjutkan dengan uji hipotesis. Hasil uji hipotesis diperoleh, Fhit perlakuan 78,46> $\mathrm{F}_{\text {daf }} 4,94$ terdapat pengaruh perlakuan pemberian fitohormon pada tinggi tanaman tebu. Uji data BNJ (Beda Nyata Jujur), dimna 
untuk tahapan ini untuk mengetahui pengaruh larutan fitohormon alami yang terdapat pada bawang merah dan air kelapa, hasil uji BNJ 0,01 dengan hasil 33,71 dapat diketahui nilai setiap perlakuan berbeda dengan nilai BNJ 0,01 artinya perlakuan pertama pemberian tanah pasir dan tanah merah tanpa menggunakan fitohormon sampai dengan perlakuan keempat pemberian pupuk kandang dan fitohormon kombinasi larutan bawang merah dan air kelapa memberikan pengaruh tetapi tidak begitu segnifikan, yang mengalami pengaruh segnifikan yaitu perlakuan ketiga pemberian pupuk kandang dan fitohormon larutan air kelapa dengan tinggi tanaman $187,83 \mathrm{~cm}$.

Pengaruh larutan fitohormon pada pertumbuhan tanaman tebu ternyata mempengaruhi pertumbuhan tinggi tanaman tebu, perlakuan yang paling memberikan pengaruh nyata pada pertumbuhan tinggi tanaman tebu yaitu perlakuan ketiga pemberian pupuk kandang dan fitohormon larutan air kelapa yang diberi pupuk kandang dan dilakukan penyiraman menggunakan larutan fitohormon air kelapa dengan konsentrasi $16,6 \mathrm{ml}$ yang menghasilkan tanaman tebu setinggi $187,8 \mathrm{~cm}$. Hal ini dikarenakan didalam larutan air kelapa mengandung fitohormon auksin dan gibrelin yang dimana fungsi dari hormon auksin itu sendiri berperan dalam meningkatkan pertumbuhan akar tanaman, juga berperan dalam meningkatkan pertumbuhan batang tanaman tebu, pertumbuhan batang yang di maksud adalah pertumbuhan tinggi dan diameter batang tanaman tebu. Hormon auksin berperan dalam meningkatkan protoplasma sel pada batang, yang akan membentuk batang baru atau mengasilkan pertambahan tinggi batang tanaman tebu (Djamhuri dkk, 2011).

\section{Pertumbuhan Helai DaunTanaman Tebu (Saccharum officinarum L.)}

Berdasarkan hasil statistik jumlah helai daun tanaman tebu dapat diketahui bahwa perlakuan pertama pemberian tanah pasir dan tanah merah, perlakuan kedua pemberian pupuk kandang dan fitohormon bawang merah, perlakuan ketiga pemberian pupuk kandang dan fitohormon air kelapa, normal dan yang tidak normal Perlakuan keempat pemberian pupuk kandang dan fitohormon bawang merah dan air kelapa, tetapi hanya satu yang tidak normal jadi kesimpulannya data berdistribusi normal Lo $<\mathrm{L}_{\text {daf }} 0,364$ berarti terima homaka dapat disimpulkan bahwa sampel berasal dari populasi berdistribusi normal. Data yang berdistribusi normal maka akan dilanjutkan ke uji homogenitas, setelah uji homogenitas dapat diperoleh $x^{2}$ 9,21 $>\mathrm{x}^{2}{ }_{(1-0,05}$ (4-1) 11,34 dari tabel chi kuadrat yang berarti Ho diterima sehingga dapat disimpulkan bahwa sampel bervariasi homogen, dikarenakan data homogen maka di lanjutkan dengan uji Hipotesis. Hasil uji hipotesis didapat Fhit perlakuan 27,86> $F_{\text {daf }} 4,94$ terdapat pengaruh perlakuan pemberian fitohormon pada helai daun tanaman tebu.

Uji data statistika tahap terakhir yaitu uji BNJ (Beda Nyata Jujur), dimana pada tahap ini untuk mengetahui pengaruh larutan fitohormon terdapat pada bawang merah dan air kelapa, hasilnya nilai setiap perlakuan dengan BNJ 0,01 diperoleh perlakuan pertama merupakan perlakuan terkecil dan perlakuan kedua sampai keempat memiliki persamaan pengaruh, 
artinya tidak terdapat perbedaan yang segnifikan antara perlakuan kedua pemberian pupuk kandang dan fitohormon bawang merah, perlakuan ketiga pemberian pupuk kandang dan fitohormon air kelapa dan perlakuan keempat pemberian pupuk kandang dan fitohormon bawang merah dan air kelapa. Berdasrkan data hasil penelitian dan perhitungan terhadap jumlah helai daun tebu yang dilakukan setiap minggu sampai 8 minggu diketahui bahwa daun pada tanaman tebu yang paling banyak mempunyai helai daun yaitu perlakuan P3 pemberian pupuk kandang dan fitohormon air kelapa dengan penambahan larutan air kelapa. Pemberian jenis fitohormon air kelapa menunjukkan perlakuan yang paling baik terhadap pertumbuhan jumlah helai daun pada tanaman tebu, air kelapa sebagai fitohormon terbaik dalam pertumbuhan tanaman tebu dikarenakan air kelapa memiliki tambahan hormon yang tidak ada pada larutan fitohormon bawang merah, yaitu hormon sitokinin. Hormon sitokinin yang berfungsi sebagai pembentuk sel-sel baru (tunas). Jumlah daun anakan tebu dari perlakuan fitohormon air kelapa mendapatkan hormon gibrelin dan sitokinin yang bekerja sama untuk menghasilkan jumlah anakan daun pada tanaman tebu. Kedua hormon tersebut sangat penting dalam proses pertumbuhan dan jumlah helai daun pada tanaman (Ariyanti, 2018).

\section{Pertumbuhan Diameter Batang Tanaman Tebu (Saccharum officinarum L.)}

Berdasarkan hasil statistika diameter batang tanaman tebu dapat diketahui bahwa perlakuan pertama pemberian tanah pasir dan tanah merah tidak normal tetapi perlakuan kedua pemberian pupuk kandang dan larutan fitohormon bawang merah, perlakuan ketiga pemberian pupuk kandang dan larutan air kelapa dan perlakuan keempat pemberian pupuk kandang dan fitohormon kombinasi larutan bawang merah dan air kelapa semua perlakuan nya normal data berdistribusi normal $\mathrm{Lo}<\mathrm{L}_{\mathrm{daf}} 0,364$ berarti terima homaka dapat disimpulkan bahwa sampel berasal dari populasi berdistribusi normal. Data yang berdistribusi normal maka akan dilanjutkan ke uji homogenitas, setelah uji homogenitas dapat diperoleh $\mathrm{x}^{2}-19,24>\mathrm{x}^{2}{ }_{(1-0,05}$ (4-1) 11,34 dari tabel chi kuadrat yang berarti Ho diterima sehingga dapat disimpulkan bahwa sampel bervariasi homogen, dikarenakan data homogen maka di lanjutkan dengan uji hipotesis. Hasil uji hipotesis yang didapat Fhit perlakuan 85,77> $F_{\text {daf }} 4,94$ terdapat pengaruh perlakuan pemberian fitohormon pada diameter batang tanaman tebu.

Uji data statistik tahap yang terakhir yaitu uji BNJ (Beda Nyata Jujur) dimana tahap ini untuk mengetahui pengaruh larutan fitohormon terdapat pada bawang merah dan air kelapa, hasilnya nilai setiap perlakuan. Nilai setiap perlakuan berbeda dengan nilai BNJ 0,01 artinya semua perlakuan terdapat pengaruh nyata yang segnifikan, dengan nilai terkecil yaitu perlakuan pertama pemberian tanah pasir dan tanah merah dengan diameter batang $4,5 \mathrm{~cm}$ dan perlakuan yang terbaik yaitu perlakuaan ketiga pemberian pupuk kandang dan fitohormon larutan air kelapa dengan nilai 7 dengan menggunakan penambahan larutan air kelapa, kandungan fitohormon pada air kelapa seperti auksin dan gibrelin 
keduanya dikombinasikan dapat memacu pertumbuhan pada tanaman dan mendorong pembelahan sel pada kambium sehingga mendukung pertumbuhan diameter batang (Setiawan $\mathrm{dkk}, 2013)$

Berdasarkan penelitian yang telah dilakukan tentang Penambahan Larutan Bawang Merah (Allium Cepa L.) dan Air Kelapa (Cocos Nucifera L.) Sebagai Fitohormon Alami Pada Pertumbuhan Tanaman Tebu (Sacchanum Officinarum L.) Sebagai Sumber Belajar Biologi berupa video yang digunakan pada materi pertumbuhan dan perkembangan, dimana hasil dari penelitian menunjukkan bahwa larutan fitohormon alami air kelapa memberikan pengaruh nyata terhadap pertumbuhan tanaman tebu yang menunjukkan pengaruhnya yaitu tinggi tanaman tebu, jumlah helai daun tanaman tebu, dan diameter batang tanaman tebu. Proses pembuatan video pembelajaran dengan durasi 12 menit dengan materi pertumbuhan dan perkembangan, isi dari materi tersebut yaitu pertumbuhan merupakan pristiwa perubahan biologi yang terjadi pada mahluk hidup yang berupa pertambahan ukuran (volume massa, dan tinggi). Perkembangan merupakan proses menuju tercapainya kedewasaan atau tingkat yang lebih sempurna (kompleks). Salah satu faktor yang mempengaruhi pertumbuhan pada tumbuhan yaitu fitohormon.

\section{KESIMPULAN}

Larutan bawang merah memberikan pengaruh yang sangat nyata terhadap petumbuhan tanaman tebu (Saccharum officinarum L.). Larutan fitohormon alami yang paling baik dalam meningkatkan pertumbuhan tanaman dan jumlah helai daun serta diameter batang pada tanaman tebu yaitu perlakuan dengan menggunakan pupuk kandang dan fitohormon air kelapa dengan konsentrasi $25 \%$. Produk sumber belajar berupa video layak atau valid untuk digunakan sumber belajar bagi peserta didik dalam materi pertumbuhan dan perkembangan.

\section{DAFTAR RUJUKAN}

Agustian, N. dan Lusi, M. 2010. Rhizobakteria Penghasil Fitohormon IAA Pada Rhizosfir Tumbuhan Semak Karamunting, Titonia, dan Tanaman Pangan. Jurnal Solum VII (1),h. 49-60.

Ariyanti, M., Cucu, S., dan Yudithia, M. 2018. Pengaruh Pertumbuhan Kelapa (Cococ nucifera L.) dengan Pemberian Air Kelapa. 2(2), h. 201-212.

Djamhuri, E. 2011. Pemanfaatan Air Kelapa Untuk Meningktakan Pertumbuhan Stek Pucuk Meranti Tembaga (Shorea leprosula miq.) Jurnal Silvikultur Tropika. 02(01), h. 5-8.

Khair, H. Dulah, A. dan Zailan, R. H. 2013 Pengaruh Konsentrasi Ekstrak Bawang Merah dan Air Kelapa Terhadap Pertumbuhan Stek Tanaman Melati Putih (Jasminum sambac L.) 18(2), h. 130-138

Misran, E. 2005. Industri Tebu Menuju Zero Waste Industry. Jurnal Teknologi Proses 4(2), h. 6-10.

Muswita. 2011. Pengaruh Konsentrasi Bawang Merah (Allium Cepa L) Terhadap Pertumbuhan Setek Gaharu (Aquilaria malaccensis OKEN) 13(1), h. 15-20. 
Ngatimin., Sri, N, A., dan Ratnawati, S. 2019. Penyakit Benih \& Teknik

Pengendaliannya. Yogyakarta: LeutikaPro

Nur., dan Ernawati, T.M. 2017. Rospek Pengembangan Usaha Pengolahan Gula Merah Tebu di Desa Suka Makmur Kecamatan Wih Pesam Kabupaten Bener Meriah. Jurnal S. Pertanian 1(11), h. 929-937.

Safitri, M. D., Kus, H., Kuswanto, F. H., dan Sunyoto. 2017. Pengaruh dosis pupuk kandang kambing dan pupuk hayati terhadap pertumbuhan dan hasil jagung (Zea maysb L.). Jurnal Agrotek Tropika 5(2), h. 75-79.

Setiawan, Puji., Balonggu, S., dan Jonata, G. 2013. Pengaruh Perendaman Benih Kokoa Dalam Air Kelapa dan Pemberian Pupuk NPKMg (15-15-6-4) Terhadap Pertumbuhan Bibit Kakao (Therobroma cacao L.) Jurnal Online Agroekoteknologi.1(4), h. 1265-1276

Sukmadi, dan R. Bambang. 2013.

Aktivitas Fitohormon Indole-3Acetic Acid (IAA) Dari Berbagai Isolasi Bakteri Rizosfer Dan Endofit. Jurrnal Sains dan Teknologi Indonesia. 14(3), h. 221227 